\title{
PHYLOGEOGRAPHY OF OLIGORYZOMYS LONGICAUDATUS (RODENTIA: SIGMODONTINAE) IN TEMPERATE SOUTH AMERICA
}

\author{
R. Eduardo Palma, ${ }^{*}$ Eric Rivera-Milla, Jorge Salazar-Bravo, Fernando Torres-Pérez, Ulyses F. J. Pardiñas, \\ Pablo A. Marquet, Angel E. Spotorno, Andrés P. Meynard, and Terry L. Yates \\ Centro de Estudios Avanzados en Ecología y Biodiversidad and Departamento de Ecología, \\ Pontificia Universidad Católica de Chile, Casilla 114-D, Santiago 6513677, Chile (REP, FTP, PAM, APM) \\ Developmental Neurobiology, University of Konstanz 78467, Konstanz, Germany (ERM) \\ Department of Biological Sciences, Texas Tech University, Lubbock, TX 79409, USA (JSB) \\ Centro Nacional Patagónico (CENPAT-CONICET), Bvd. G. Brown s/n Casilla de Correo 128, 9120 Puerto Madryn, \\ Chubut, Argentina (UFJP) \\ Programa de Genética Humana, Instituto de Ciencias Biomédicas, Facultad de Medicina, Universidad de Chile, \\ Casilla 70061, Santiago, Chile 6530499 (AES) \\ Department of Biology and Museum of Southwestern Biology, The University of New Mexico, Albuquerque, \\ NM 87131, USA (TLY)
}

\begin{abstract}
Phylogeographic relationships were evaluated at the intraspecific level using nucleotide sequence data from the mitochondrial cytochrome $b$ gene of representative specimens of "colilargo" (Oligoryzomys longicaudatus) from 31 localities, along its distributional range over a large part of the western Andes and southern Argentina. Based on approximately 1,000 base pairs (bp), we recognized a single species on both the Chilean and the Argentinean side as far as at least latitude $51^{\circ} \mathrm{S}$, rejecting the subspecific distinctiveness of longicaudatus and philippi. We thus placed the latter in full synonymy with $O$. longicaudatus as earlier studies proposed, and enlarged its range as far as Torres del Paine, about $51^{\circ} \mathrm{S}$. The occurrence of subspecies in this range is doubtful given the low sequence divergence values and the absence of significant associations between haplotypes and their geography. Additionally, we hypothesized that the entrance of this species into the Chilean side of the Andes mountains occurred through the Patagonian forests of southern Argentina, with further dispersal to the north from the south.
\end{abstract}

Key words: Argentina, Chile, cytochrome $b$ gene, Oligoryzomys longicaudatus, phylogeography

Oligoryzomys Bangs, 1900 is a genus of small mice recognized in the New World as part of the Tribe Oryzomyini (Muridae: Sigmodontinae). Until recently, this taxon was recognized as a subgenus of Oryzomys, but further morphological revisions based on external, cranial, tooth, and stomach morphology raised its taxonomic status to the generic level (Carleton and Musser 1989). Using these morphological data researchers also concluded that Oligoryzomys is a monophyletic lineage. This was later corroborated by protein electrophoresis and partial sequences of the cytochrome $b$ gene (Dickerman and Yates 1995; Myers et al. 1995). Currently, 15 species are recognized in the genus (Musser and Carleton 1993) distributed throughout the

*Correspondent: epalma@genes.bio.puc.cl

(C) 2005 American Society of Mammalogists www.mammalogy.org
Neotropics from Mexico (e.g., Oligoryzomys fulvescens) southward to Argentina and Chile (e.g., O. longicaudatus).

Osgood (1943) classified all Chilean Oryzomys as O. longicaudatus although he differentiated it into 3 subspecies based on subtle morphological features (Mann 1978; Osgood 1943). The ranges of the originally recognized subspecies are roughly congruent with 3 of Chile's major ecogeographic regions: $O$. $l$. longicaudatus from the Mediterranean region (Copiapó Valley south to the northern parts of the Province of Concepción); O.l. philippi in the temperate forest (northern Concepción Province south to ca. $50^{\circ} \mathrm{S}$ ), and O. l. magellanicus in the Patagonian and Fuegian forests south of approximately $50^{\circ}$. In Argentina $O$. longicaudatus occurs from approximately $32^{\circ} \mathrm{S}$ (SW of Mendoza) to approximately $48^{\circ} \mathrm{S}$ ( $\mathrm{N}$ of Santa Cruz Province). However, a further comprehensive phenetic revision of the species, including external, cranial, bacular, chromosomal, and allozyme characters led to the separation of the southernmost subspecies as O. magellanicus (Gallardo and Palma 1990; 
Palma 1987). In southern Chile $O$. longicaudatus is mainly associated with Nothofagus forests, the ecotone between these forests and the Patagonian steppe (Monjeau et al. 1998; Pearson 1983, 1987), whereas in central Chile it occurs in bushy areas with mesic conditions (Mann 1978). Some Oligoryzomys collected in the vicinity of San Blas (Buenos Aires, Argentina) have also been asigned to longicaudatus, as the subspecies O. l. pampanus (Massoia 1973).

In Chile O. longicaudatus is best known as "colilargo" (long-tailed mouse), although its traditional name has been "long-tailed pygmy rice rat." Earlier studies that considered external, cranial, and bacular morphology of this species, and that included representative specimens of several populations throughout its range, failed to disclose evidence of subspecific differentiation that would distinguish between longicaudatus and philippi (Gallardo and Palma 1990). However, populations ascribed to $O$. magellanicus exhibited strong patterns of differentiation when compared with northern populations for almost all morphological features analyzed. For example, Gallardo and Palma (1990) showed differences in bacular morphology between longicaudatus-philippi and magellanicus, with the baculum of the latter being significantly larger than that of the northern taxon. Chromosomally, the same study showed that the diploid number between the karyotypes of $O$. l. longicaudatus and $O$. l. philippi were identical $(2 \mathrm{n}=56)$; that of $O$. l. magellanicus exhibited $2 \mathrm{n}=54$ (Gallardo and Patterson 1985; Palma 1987). Finally, phenetic analyses of allozyme data comparing 15 loci from 60 specimens among 10 populations of $O$. l. longicaudatus and O. l. philippi in Chile (between Coquimbo in Region IV and Aysén in Region XI; data are not available for $O$. l. magellanicus) exhibited high levels of genetic similarity (Palma 1987). Thus, based on the strong morphologic and genetic uniformity detected among populations along the range of the 2 northern subspecies, Gallardo and Palma (1990) recognized a single species between $28^{\circ}$ and $50^{\circ} \mathrm{S}, O$. longicaudatus, with philippi being a full synonym of longicaudatus. The same study concluded that Patagonian populations of the southernmost subspecies (magellanicus) constituted a valid species, ranging from $50^{\circ} \mathrm{S}$, southward to the Patagonian forests and adjacent islands in Magallanes, Chile. The morphologic and genetic uniformity found in the range of $O$. longicaudatus, coupled with the ecological evidence that showed high vagility of this species (Murúa et al. 1986), led to the inference of high gene flow among Oligoryzomys populations along the latitudinal gradient (Palma 1987). This is of great importance because this species is a major reservoir for 1 of the several hantavirus strains, the Andes strain, which produces hantavirus pulmonary syndrome (HPS) in humans (Padula et al. 2000; Toro et al. 1998).

Biogeographically, the occurrence of Oligoryzomys in Chile has been hypothesized to be the result of dispersal from Argentina, particularly through the lower Andean elevations where the Nothofagus forests are continuous throughout the Andes (Gallardo and Palma 1990; Palma 1987). Further displacement of the species, particularly northward expansion in Chile, might have been facilitated by the series of glacial cycles that severely affected southern forests during the Pleistocene glaciations. During these glaciations, there was a northward shift in vegetation and associated fauna along the coastal mountain range and the central valley of Chile (Villagrán and Hinojosa 1997). This hypothesis has been preferred to an alternative northern scenario of entrance to the Chilean side, mainly because of the occurrence of the Atacama Desert in the north (since Miocene times) that certainly has constituted a major barrier for the dispersal of this taxon. In fact, some ecological studies have established the affinity of the "colilargo" for forest and mesic areas that are not present in the north (Kelt et al. 1994; Meserve et al. 2003; Murúa et al. 1986).

The current study was designed to evaluate the hypothesis of genetic and morphological uniformity along the latitudinal gradient of Oligoryzomys longicaudatus in Chile, and to reevaluate the existence of subspecies in its range. We additionally included specimens from 2 localities that lie in the range of O. magellanicus according to Gallardo and Palma (1990). Furthermore, we tested whether southern forms of $O$. longicaudatus constitute the basal populations because the Temperate Chilean Forests have been hypothesized to be the area of entrance from Argentina to Chile (Gallardo and Palma 1990; Palma 1987). To achieve these goals we sequenced the cytochrome $b$ mitochondrial gene from 33 specimens of $O$. longicaudatus and $O$. magellanicus, encompassing the entire latitudinal range of the former taxon, with specimens from 27 localities in Chile and 4 in Argentina.

\section{Materials ANd Methods}

Tissues and specimens analyzed.-Voucher specimens for the individuals sequenced in this study were deposited in the Colección de Flora y Fauna Profesor Patricio Sánchez Reyes (SSUC), Departamento de Ecología, Pontificia Universidad Católica de Chile, Santiago, Chile; Colección de Mamíferos del Centro Nacional Patagónico (CENPAT), Puerto Madryn, Argentina (field numbers UP and LB); the Museum of Southwestern Biology (MSB), Department of Biology, University of New Mexico; and the Instituto de la Patagonia (CZIP), Universidad de Magallanes, Chile. Tissues and other data associated with each specimen are cross-referenced directly to each voucher specimen and stored in the collection using a special field catalog number, the NK number used by the SSUC and the MSB. GD is the field catalog of Guillermo D'Elia (specimens not yet cataloged and stored at Museo Nacional de Historia Natural from Paraguay). A detailed list of the specimens sequenced per locality is given in Appendix I. We followed the ASM Guidelines during the collection and care of the animals used in this work (Animal Care and Use Committee, 1998).

Nucleotide sequence analyses.-DNA was extracted from frozen liver and blood samples according to the technique described by Laird et al. (1991). The mitochondrial cytochrome $b$ gene (approximately $1,000 \mathrm{bp}$ ) was amplified for 33 individuals representing 31 localities (33 haplotypes) throughout the range of $O$. longicaudatus. Given the low rate of variation observed for the cytochrome $b$ gene when analyzed at the intraspecific level (see results), in the majority of cases we sequenced a single specimen per locality. This low variability has also been shown for the same molecular marker when sequenced in related sigmodontine taxa (Smith et al. 2001; Smith and Patton 1999; Steppan 1998). The first half of the gene was amplified using primers MVZ 07 and MVZ 26 (Smith and Patton 1993) with the following thermal cycle (35 cycles): denaturation for $1 \mathrm{~min} 30 \mathrm{~s}$ at $94^{\circ} \mathrm{C}$, annealing for $30 \mathrm{~s}$ at $54^{\circ} \mathrm{C}$, and extension for $1 \mathrm{~min} 10 \mathrm{~s}$ at $72^{\circ} \mathrm{C}$. The 
2nd half of the gene was amplified with primers LBE 05 (5' CTA CAC GAA ACA GGC TC 3') and H 15767 (Edwards et al. 1991) using the same protocol as above, except that annealing was modified to $59^{\circ} \mathrm{C}$ for $25 \mathrm{~s}$, with a total of 30 cycles. Double-stranded PCR products were purified with Wizard PCR Preps (Promega) and Qiaquik (Qiagen). Cycle sequencing was performed (Murray 1989) using primers MVZ 07, LBE 05, and H 15767 labeled with the Big Dye Terminator kit (Perkin Elmer, Norwalk, Connecticut). The sequencing reactions were analyzed on an Applied Biosystems Prism 310 (Foster City, California) automated sequencer. Sequences were aligned using the ClustalW program (Higgins et al. 1996), and by eye, allocating the proper codon position from the beginning of the cytochrome $b$ sequence using the Mus musculus sequence as a reference (Bibb et al. 1981). We used MEGA software (Molecular Evolutionary Genetic Analysis, version 1.02-Kumar et al. 1993) to obtain the frequencies of nucleotide bases in all "colilargos," the number of transitions and transversions between every pair of taxa, and the transition/transversion rates.

Phylogenetic analysis.-Phylogenetic analysis was conducted using the maximum-likelihood algorithm available in PAUP* 4.0 (Swofford 2002). To choose the best fitting model of sequence evolution we used Modeltest 3.06 (Posada and Crandall 1998). The Akaike information criterion (AIC-Akaike 1974) identified the transversion + gamma model $(\mathrm{TVM}+\mathrm{G})$ as optimal $(-\operatorname{lnL}=2105.6758$, AIC 4227.3516), with base frequencies $\mathrm{A}=0.3011, \mathrm{C}=0.2751, \mathrm{G}=0.1338$, $\mathrm{T}=0.2900$; and substitution models $\mathrm{A}-\mathrm{C}=2.9512, \mathrm{~A}-\mathrm{G}=7.6073$, $\mathrm{A}-\mathrm{T}=1.4982, \mathrm{C}-\mathrm{G}=1.2048, \mathrm{C}-\mathrm{T}=7.6073, \mathrm{G}-\mathrm{T}=1$. The optimal base composition, substitution rate matrix, and among site substitution rate heterogeneity parameters were simultaneously estimated during the maximum-likelihood heuristic search. The proportion of invariable sites (I) was 0 . Reliability of nodes was estimated by maximum-likelihood bootstrap percentages (Felsenstein 1985) obtained after 100 pseudoreplications using the previously estimated maximum-likelihood parameters with tree bisection reconnection branch swapping. We rooted the tree with the outgroup criteria, using Oligoryzomys fornesi. We used this species as the outgroup because an ongoing phylogeny of the genus based on the cytochrome $b$ and the NADH1 mtDNA genes shows that $O$. longicaudatus is part of a clade that includes $O$. fornesi from the Chaco and Andean regions in the Neotropics (Palma et al. in litt.).

The amount of sequence divergence between groups (i.e., subspecies per ecogeographic region) was evaluated using MEGA software. We considered whole transitions (ts) and transversions (tv) for all codon positions using the Tamura-Nei and Kimura-2-parameter (K2P) models available in MEGA. Grouping of localities by subspecies and ecoregions was as follows (ecogeographic regions according to Armesto et al. in press; Fig. 1): a) O. l. longicaudatus (Mediterranean region): La Silla, Fray Jorge, Salamanca, Quebrada del Tigre, San Antonio, Rínconada Maipú, Apoquindo, San Fernando, Romeral, Bullileo, Quillón, Tucapel; b) O. l. philippi (Temperate forests region): Carahue, Temuco, Villarrica 048, Villarrica 083, Quetrupillán, Zapala, Chos Malal, Las Breñas, Panguipulli, Riñihue, Chiloé 656, Chiloé 659, Mininco 245, Mininco 268, Río Simpson, Alto Río Ibañez; c) $O$. $l$. magellanicus (Patagonian Forest region): Torres del Paine, Penitente; d) O. l. pampanus: San Blas UP 374, San Blas UP 377.

Phylogeographic and genetic structure analyses.-We conducted a Mantel test (Mantel 1967) to see if there was any correlation between the genetic distance obtained from a Tamura-Nei (TN) distance matrix using MEGA and the geographic distance among specimen localities measured in $\mathrm{m}$. For this analysis we used the Mantel program 2.0 (Liedloff 1999) with 100 permutations. Additionally, we conducted an analysis of molecular variance (AMOVA-Excoffier et al., 1992) at 2 hierarchical levels (i.e., within subspecies and between subspecies)

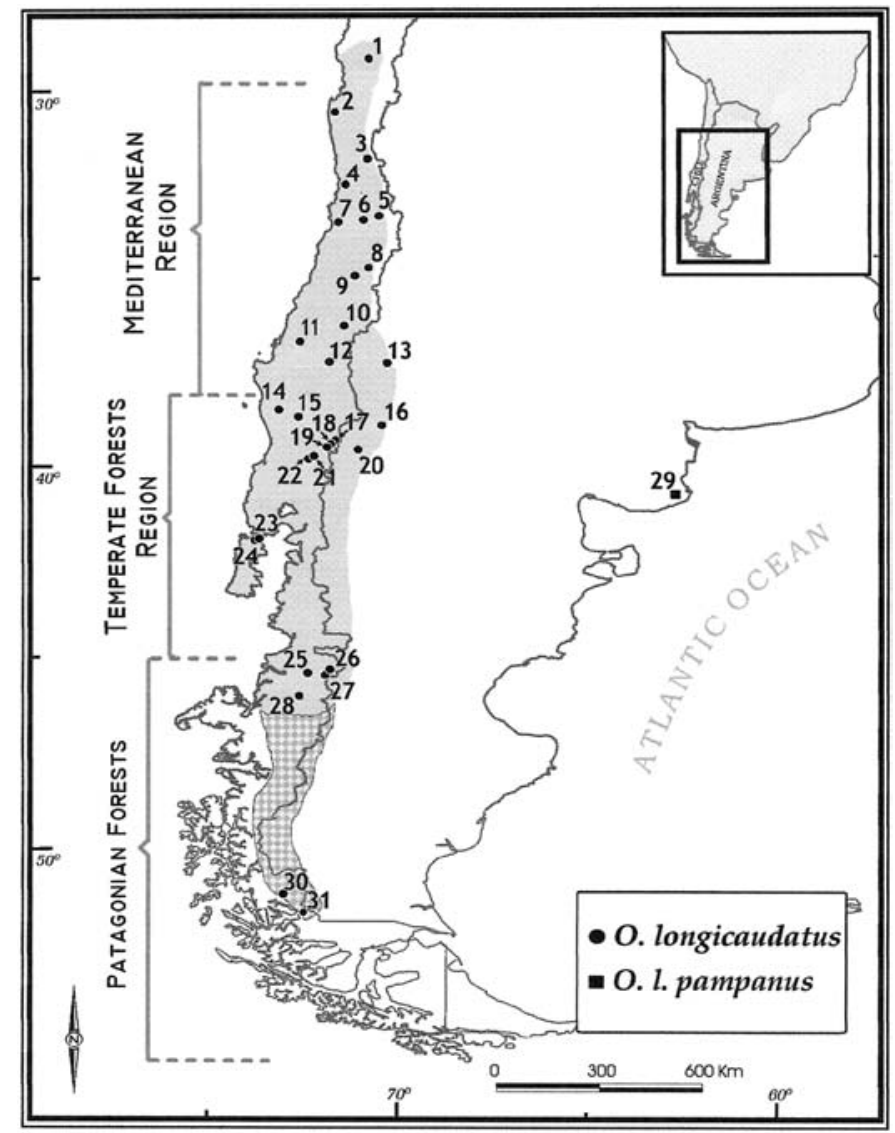

Fig. 1.-Approximate range of distribution of Oligoryzomys longicaudatus in Chile and Argentina (shaded area); crossed lines indicate species range extension; circles represent other localities where the species has been reported in Argentina. Numbers indicate localities sampled corresponding to four subspecies. O. l. longicaudatus: 1) La Silla, 2) Fray Jorge, 3) Salamanca, 4) Quebrada del Tigre, 5) Apoquindo, 6) Rinconada de Maipú, 7) San Antonio, 8) San Fernando, 9) Romeral, 10) Bullileo, 11) Quillón, 12) Tucapel, 13) Chos Malal; O. l. philippi: 14) Carahue, 15) Temuco, 16) Zapala, 17) Quetrupillán, 18) Villarrica 083, 19) Villarrica 048, 20) Las Breñas, 21) Panguipulli, 22) Riñihue, 23) Chiloé 659, 24) Chiloé 656, 25) Río Simpson, 26) Mininco 245, 27) Mininco 268, 28) Río Ibañez; $O . l$. pampanus: 29) San Blas; O. l. magellanicus: 30) Torres del Paine, 31) Río Penitente.

using ARLEQUIN version 2.000 which takes into account both haplotype frequency and molecular divergence (Schneider et al. 2000). We pooled localities for each subspecies according to the ecogeographic regions where they were described (see above). Finally, we conducted a mismatch-distribution analysis, using ARLEQUIN, for all sequences to detect whether or not different haplogroups occurred, and to evaluate if the frequency distribution of haplotypes in Oligoryzomys followed any particular modal distribution (Rogers and Harpending 1992).

A haplotype network was constructed using TCS program version 1.0 (Clement et al. 2000), and clades were nested according to rules outlined in Templeton et al. (1992). GEODIS version 2.0 (with 10,000 resampling events-Posada et al. 2000) was used to test for significant associations between haplotype and geography. When significant associations were detected, an inference key given by Templeton (2004) was used to determine the likely cause of associations. 


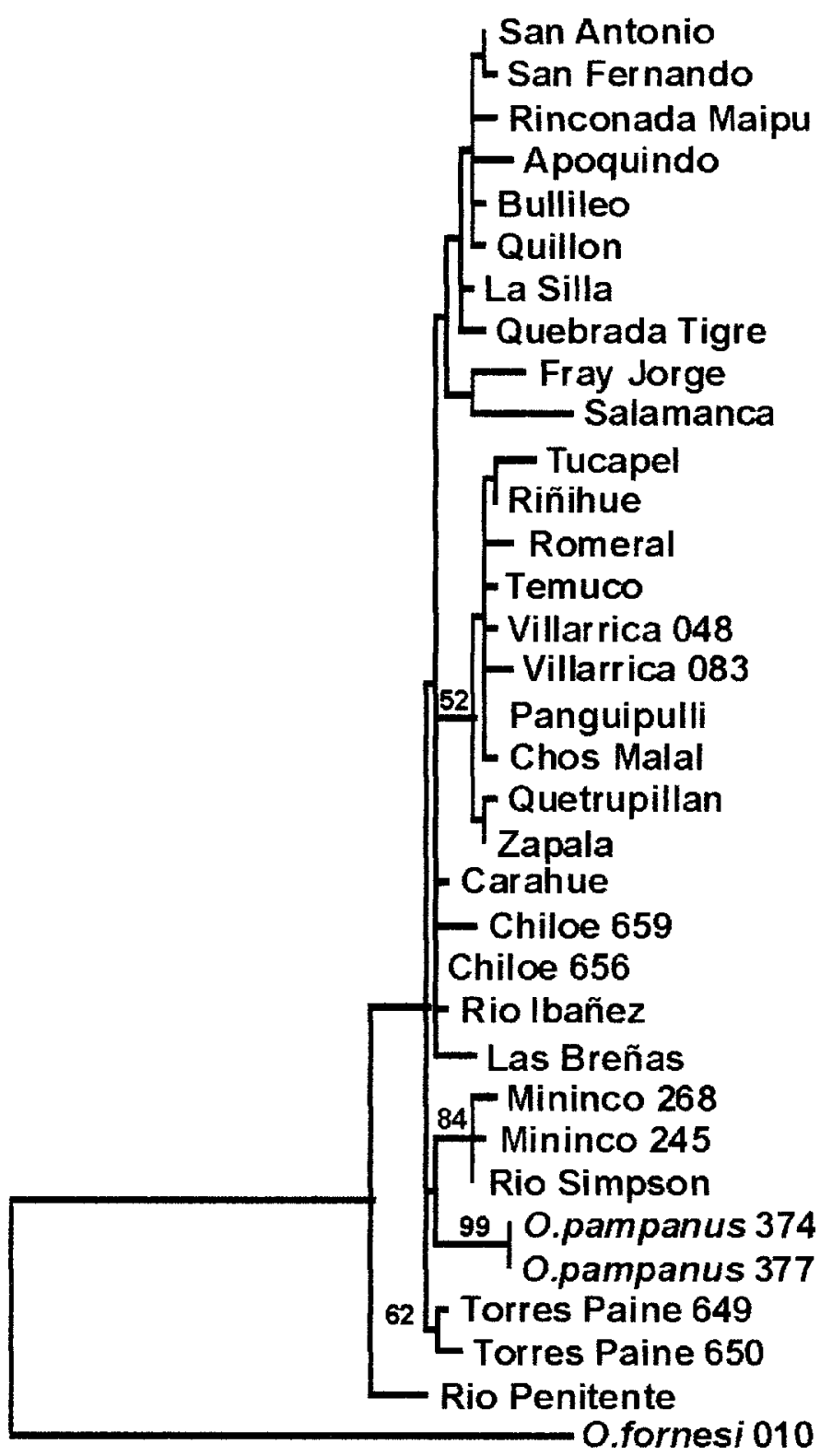

0.005 substitution s/site

Fig. 2.-Maximum-likelihood tree obtained from the cytochrome $b$ gene sequences of $O$. longicaudatus. Numbers on nodes represent 100 bootstrap replicates.

\section{RESUlts}

Phylogenetic analyses.-Figure 2 shows the tree obtained from maximum-likelihood, with Modeltest parameters as given above. The-lnL value for this tree was 2105.6758. Bootstrap values were low, and those shown in the tree represent values over $50 \%$; while branch lengths were mostly short. The tree clearly shows recovery of a single clade (with the exclusion of Río Penitente) representing localities of southcentral Chile and Argentina between San Antonio and Torres del Paine and that should be recognized as $O$. longicaudatus. In this clade, we distinguished a southernnorth latitudinal trend on which southern localities were more basal (e.g., Mininco, Río Simpson, Torres del Paine) than northern localities that were recovered as the most derived (e.g., San Antonio-Quebrada del Tigre, closely tied to Fray Jorge-Salamanca). This clade also included adjacent Argentinean localities, as well as $O . l$. pampanus from Buenos Aires Province, and specimens from Torres del Paine National Park $\left(51^{\circ} \mathrm{S}\right)$ that according to Gallardo and Palma (1990) should be recognized as O. magellanicus. The representative from Río Penitente $\left(52^{\circ} \mathrm{S}\right)$ constitutes the $1 \mathrm{st}$ outgroup to the longicaudatus clade.

Nucleotide sequence variation, structure analyses, and nested clade analyses. - We observed a ts/tv ratio of 4.15 and 4.17 using $\mathrm{K} 2 \mathrm{P}$ and $\mathrm{TN}$, respectively, with strong bias towards ts of the CT type. Whole sequence divergence using both $\mathrm{K} 2 \mathrm{P}$ and $\mathrm{TN}$ models of sequence evolution was $0.9 \%$. Divergence values between $O$. longicaudatus subspecies varied between 0.9 and $1.3 \%$ for all codon positions. The sequence divergence between $O$. longicaudatus (all pooled localities) and the outgroup $O$. fornesi, using both nucleotide variation criteria, was 12.9. The Mantel test did not show any significant association between the distance matrices $(P=0.05$; critical value $=1.645: G=0.1296$, Mantel coefficient $(Z)=6608.22$, $r=0.0172$ ). However, the total $F_{s t}$ value obtained from the AMOVA analysis for the 4 nominal subspecies showed structuring of groups (i.e., the existence of subspecies; $F_{s t}=$ $0.2556, P<0.01)$.

Haplotypes that differed by as many as 13 single mutational steps were parsimoniously connected at the $95 \%$ confidence level, resulting in the construction of one network with a total of 33 haplotypes (Fig. 3). The GEODIS analysis revealed no significant association in the geographic distance analysis; thus we failed to reject the null hypothesis of no geographical association in all comparisons, including the entire clade level. At level 4 we ended with 3 clades: $4-1$ was constituted mostly by $O$. l. philippi haplotypes and haplotypes from Tucapel and Romeral (O. l. longicaudatus); 4-2 included O. l. pampanus, $O$. l. magellanicus, and the localities of Mininco and Río Simpson (O. l. philippi); the last clade, 4-3, contained most of the $O . l$. longicaudatus haplotypes. Finally, the mismatch distribution analysis showing the relationship between the number of differences between haplotypes and haplotype frequency exhibited a unimodal curve (Fig. 4).

\section{DisCUSSION}

Phylogenetic analysis.-Recent molecular calibrations placed the differentiation of South American sigmodontines between 4.5 and 9.5 million years ago, with the origin of Oligoryzomys occurring around 8 million years ago (Smith and Patton 1999). Carleton and Musser (1989) suggested that the evolution of the genus Oligoryzomys proceeded in stages and probably involved the repeated invasion of this genus into several environments in the Neotropics, from the uplands of the Andes (e.g., O. andinus) to lowlands, forests, savannas, and shrublands.

Using maximum-likelihood with Modeltest parameters we obtained a tree that-with the exclusion of Río Penitente- 


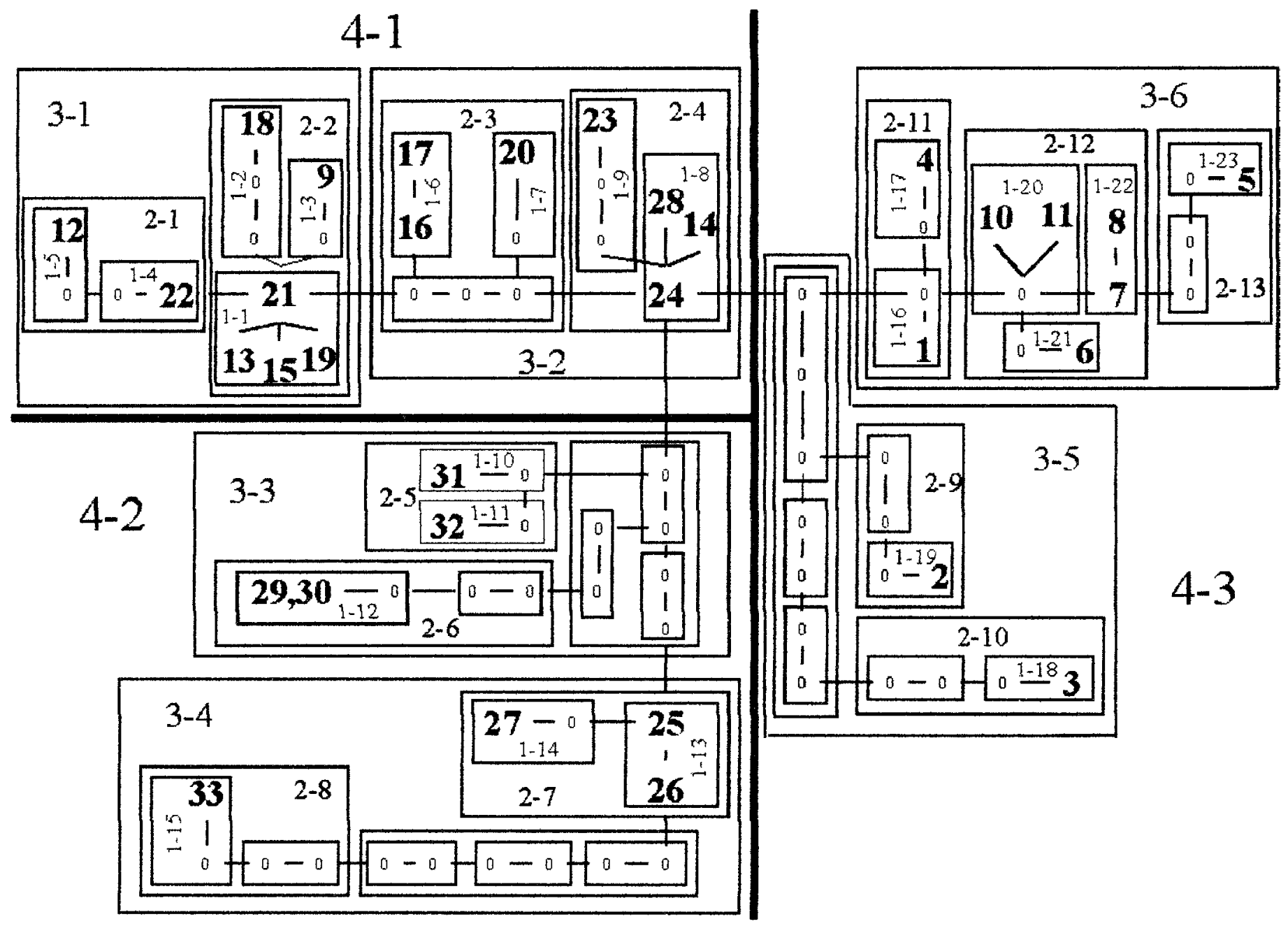

Fig. 3. - Unrooted cytochrome $b$ haplotype network for $O$. longicaudatus using TCS (version 1.0—Clement et al. 2000), and their associated nested design according to rules outlined in Templeton et al. (1995). Different haplotypes are represented by numbers in bold (see Appendix I for cross-reference with localities). Each line segment corresponds to one mutational step, and intermediate missing haplotypes are represented by zeroes.

recovered a single clade in the southcentral gradient of Chile and adjacent areas in Argentina. This clade represents currently known $O$. longicaudatus in the latitudinal gradient where subspecies longicaudatus and philippi were traditionally recognized. However, the same clade also included representatives from the southern locality of Torres del Paine that, according to Gallardo and Palma (1990), should be recognized as $O$. magellanicus. Although the 2 southernmost populations of Torres del Paine National Park occur within the range of magellanicus as currently understood, we consider them as part of the same species, $O$. longicaudatus, and refer magellanicus to its synonym, thus enlarging the range of $O$. longicaudatus at least as far as latitude $51^{\circ} \mathrm{S}$. Pardiñas et al. (2002) also documented $O$. longicaudatus at about latitude $51^{\circ} \mathrm{S}$ in Argentina. Interestingly, at the conclusion of this work we karyotyped some Oligoryzomys from Torres del Paine (located at $51^{\circ} \mathrm{S}$ ), and all forms showed an identical karyotype to that of $O$. longicaudatus $(2 \mathrm{n}=56, \mathrm{NF}=70)$, in contrast to the $2 \mathrm{n}=54$ reported for O. magellanicus (Gallardo and Patterson 1985). However, the specimen from Río Penitente $\left(52^{\circ} \mathrm{S}\right)$ might well be part of a different taxon (subspecies?) because it was recovered outside the major longicaudatus clade. Further specimens and the phylogeography of southern magellanicus will be part of a different study.

Sequence divergence, structure, and phylogeographic analyses.-In addition to the results of the maximum-likelihood tree that shows the occurrence of a single taxon in the range of $O$. longicaudatus, the sequence divergence between nominal subspecies $O$. l. longicaudatus and O. l. philippi was $0.9 \%$. This value was obtained for Chilean and Argentinean localities and when using different nucleotide criteria for sequencing evolution. This low sequence divergence pattern was even maintained when we included the southernmost population samples of Torres del Paine, because their inclusion increased the value slightly to $1.2 \%$. Other sequence divergence values for cytochrome $b$ in oryzomyines are not available; in phyllotine and akodontine mice, however, sequence divergence values fluctuate around $2 \%$ and $3.5 \%$ for subspecies (Steppan 1998 ) and about $10 \%$ for species (Smith et al. 2001). $F_{s t}$ values obtained from AMOVA showed that the subspecies are 


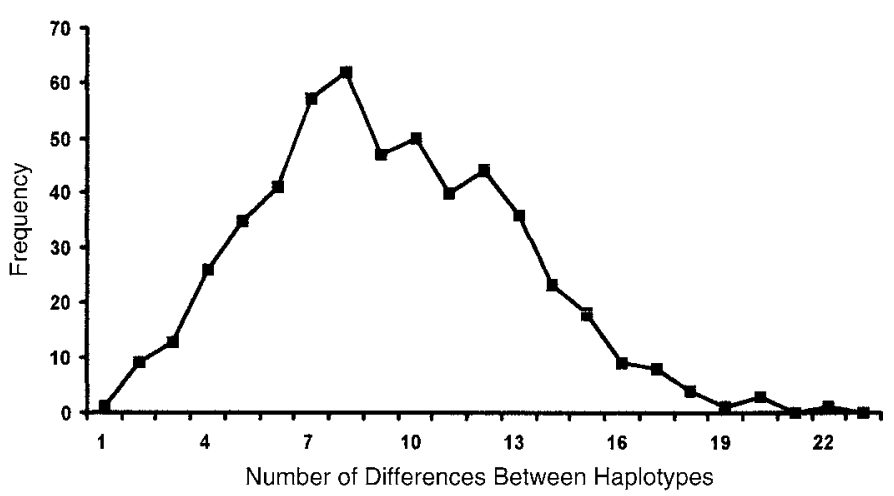

Fig. 4.- Observed pattern of mismatch distribution for an analysis that included all haplotypes of $O$. longicaudatus $(n=33)$.

structured $\left(F_{s t}=0.25506, P<0.001\right)$, although when we excluded $O$. l. pampanus, the value decreased to 0.16397 ; between longicaudatus and philippi it was $0.12663(P<$ 0.001). In spite of the decrease in these parameters, the values were still significant. Nevertheless, we did not find any significant relationships between geographic distance and the degree of genetic variation among localities represented in the range of $O$. longicaudatus, as reflected by the Mantel test. Therefore, the results suggest that gene flow is likely an important source of homogeneity among them. Consequently, we reject the subspecific distinctiveness of longicaudatus and philippi and place the latter in full synonymy with $O$. longicaudatus as earlier proposed by Gallardo and Palma (1990), thus enlarging its range to Torres del Paine, about $51^{\circ} \mathrm{S}$ (we actually believe that $O$. magellanicus occurs south of Torres del Paine). In fact, the $2 \mathrm{n}=54$ karyotype was reported in the vicinities of Punta Arenas and southern islands (e.g., Harrison Island, $54^{\circ} \mathrm{S}$ ), placing the occurrence of this taxon far south, in Patagonia (Gallardo and Patterson 1985). O. l. pampanus, on the other hand, is also part of the longicaudatus clade and might indeed constitute a subspecies, considering that the $F_{s t}$ value increased when these samples were included in the analysis. However, further sampling within the current distribution of $O$. l. pampanus (i.e., the Buenos Aires province) and the west central part in Argentina will be necessary to adequately assess the taxonomic status of this form (although it seems likely that pampanus is only known from its type locality in the Buenos Aires province).

The nested clade analysis did not exhibit significant associations between the haplotypes and their geographical positions. However, at level 4 the nominal subspecies were more or less recovered: clade 4-1 contained most of the $O . l$. philippi haplotypes, although it also included some from the northernmost subspecies (Tucapel and Romeral); clade 4-2 included the subspecies pampanus and magellanicus, and also some haplotypes in the range of philippi. Finally, clade 4-3 contained mostly haplotypes representing localities in the range of $O$. l. longicaudatus. Nevertheless, none of the 3 nestedclades at the 4- $\times$ level showed significant associations between geography and haplotypes, thus leading us to accept the null hypothesis of no geographical association. The lack of geographical association with haplotypes could be due to the occurrence of significant gene flow among populations, indicating that populations are panmictic (Templeton et al. 1995). In fact, when we performed the exact test of population differentiation under the null hypothesis of panmixia, there were no significant differences between the 4 groups (i.e., subspecies), corroborating our observation of a nested pattern. According to Templeton et al. (1995), the lack of geographical association with haplotypes could be due to a) panmixia of populations, $b$ ) inadequate sampling, or c) insufficient variability. We discard inadequate sampling because we sampled specimens from the entire distributional range of $O$. longicaudatus. Additionally, because network analysis showed 33 distinctive haplotypes, with every geographic locality represented by a haplotype (although with few mutational steps among haplotypes), we also discard a lack of variability among samples. In contrast to the $F_{s t}$ values obtained from AMOVA, all other results suggested that populations of $O$. longicaudatus, characterized by having high gene flow, might be homogenizing any possible differentiation between populations along its range. Previous geographic variation studies based on morphology and chromosomes showed a similar uniform pattern for the species. This high gene flow likely is facilitated by the high vagility and large home range reported for this species, mainly in southern Chile (Murúa et al. 1986) where it is more abundant due to its preference for mesic habitats, such as those found in the southern Temperate Forests. However, patterns of genetic homogeneity along the range of the species might also be the result of historical events, suggesting that patterns of molecular variation were shaped relatively recently in geologic time. Scenarios of expansions and retractions of biota during the last glaciation cycles of the Quaternary might have allowed multiple instances of contact between isolated populations, because several glacial cycles affected the biota of southern Chile during the Pleistocene (Villagrán 1990; Villagrán and Hinojosa 1997).

Pairwise differences between haplotypes (i.e., mismatch distribution-Rogers and Harpending 1992) for all O. longicaudatus localities pooled into 1 single sample exhibited a single peak (Fig. 4). According to the mismatch distribution model of Rogers and Harpending (1992) this pattern of pairwise differences between haplotypes represents populations expanding from a central range of distribution, whereas samples drawn from populations at demographic equilibrium show a multimodal pattern with several peaks (e.g., isolated populations that secondarily reestablish contact). Our mismatch model suggests that $O$. longicaudatus populations are characterized by recent range expansions, making their populations tightly connected genealogically (Ibrahim et al. 1996). Similar patterns were obtained for Abrothrix olivaceus in southern Argentina and Chile (Smith et al. 2001). Northern displacement of Oligoryzomys might have been facilitated during glacial times in the Pleistocene when the climate of southern Chile was colder and drier (Mercer 1983). This scenario would have allowed northern displacement of biota to less harsh climates at lower latitudes, via non-glaciated routes through the western 
slopes of the Andes and the coastal range of Chile. This fact, associated with the great vagility of the species, allowed Oligoryzomys to colonize different areas along the Chilean side of the Andes - on the coast, in the central valley, and in the foothills of the Andes-all areas where the species is found today. The distribution of Oligoryzomys has reached as far north as the Copiapó Valley in the Atacama region in Chile. As hypothesized in the maximum-likelihood topology of Fig. 2, Oligoryzomys might have reached the northernmost part of Chile more recently, after glacial recession, because a significant part of southern Patagonia was completely glaciated during the Last Glacial Maximum in Quaternary times (Holling and Schilling 1981; Moreno et al. 1999).

Biogeography.- In spite of the short branch lengths and low bootstrap values of the maximum-likelihood tree, it is possible to distinguish a south-to-north latitudinal pattern in the phylogeography of $O$. longicaudatus, suggesting that the species colonized from the south to the north of Chile. As proposed earlier by Reig (1986), it is reasonable to suggest that the southern Andes served as 1 of the areas of radiation for this group of oryzomyines. We propose the existence of lowland dispersal of Oligoryzomys forms from the highlands of the Andes to the eastern lowlands such as in northwest Argentina, a portion of the Yungas forests. In fact, O. longicaudatus has been reported to occur in that area (Mares et al. 1989; Redford and Eisenberg 1992), although recent molecular studies of $O$. longicaudatus that included populations from western Argentina did not recognize northern populations as belonging to this species (González-Ittig et al. 2002). Furthermore, these northern forms are the reservoir for a different hantavirus strain, the Oran strain (Padula et al. 2000). This northern Argentinean taxon has a disjunct distribution with respect to southern $O$. longicaudatus in Argentina and might well be related to this species. This hypothesis would sustain southern dispersal of peripheral isolates of Oligoryzomys to southern Patagonian forests, with subsequent speciation into $O$. longicaudatus. Further entrance to the Chilean side from the east might have followed the continuous Nothofagus forest vegetation and lower elevation of the Andes in the south, reaching the Chilean side. These lower elevation passes in the Andes have also been proposed to explain the evolution of another sigmodontine, Abrothrix olivaceus across the Andes (Smith et al. 2001). Oligoryzomys dispersal to central-northern Chile might have been facilitated by a northern dispersal of biota during the Pleistocene as explained above. Oligoryzomys from the south might have followed nonglaciated routes such as the Coastal Cordillera and the central valley in Chile, because glaciations to the north advanced mainly throughout the Andes (Holling and Schilling 1981; Mercer 1983; Moreno et al. 1999). This biogeographic scenario would explain the occurrence of $O$. longicaudatus in the north-central Mediterranean region whose position in the phylogenetic tree was recovered as the most derived clade. An alternative scenario would set the entrance of $O$. longicaudatus from the north, and a southward dispersal along the Chilean side might have followed, reaching temperate and Patagonian forests both in Argentina and Chile. However, this hypothesis is doubtful because the topology of the maximum-likelihood tree left southern forms as basal, supporting a southern advance from the south-thus an entrance from Argentina (about 39-40 $\mathrm{S}$ ).

$O$. longicaudatus and hantavirus.-The genetic uniformity found among $O$. longicaudatus populations along its geographic range in Chile acquires much significance because this species is the major reservoir of Andes virus (Bohlman et al. 2002; Padula et al. 2000). Seropositive specimens have been confirmed all along its distributional range (Padula et al. 2000; in litt.). Recent studies on Andes virus genetics (Medina et al. in litt.) have shown low levels of sequence divergence, mirroring the major results shown here for its reservoir species. This in turn might help researchers to understand why "colilargos" from throughout the Chilean range show an equal probability of disease transmission. Finally, we did not find any bias towards cytochrome $b$ sequence and antibody status (positive versus negative) in our sample, although several localities (e.g., Carahue and Villarrica) included both positive and negative individuals.

We concluded that the phylogeographic analyses of Oligoryzomys longicaudatus in Chile and adjacent areas in Argentina confirm the existence of this species as far as latitude $51^{\circ} \mathrm{S}$ in both Argentina and Chile. The occurrence of subspecies within this range is not supported by the results from cytochrome $b$ sequences, thus supporting previous studies based on morphology and chromosomes. Southern populations from temperate forest regions were more basal than those from the northern range, thus supporting a southern entrance of this taxon from Argentina to the Chilean side, with further dispersal to northern latitudes in Chile. Our results confirm previous analyses in connection with the morphologic and genetic homogeneity that characterize the evolutionary history of this species.

\section{RESUMEN}

Se evaluaron las relaciones filogeográficas a nivel intraespecífico del roedor sigmodontino Oligoryzomys longicaudatus ("colilargo"), usando secuencias nucleotídicas del gen mitocondrial citocromo $b$. El estudio incluyó representantes de 31 localidades cubriendo así gran parte de su rango de distribución en Chile y sur de Argentina. En base a aproximadamente $1000 \mathrm{pb}$ hipotetizamos la existencia de una única especie, O. longicaudatus, tanto en el lado chileno como argentino, descartando la existencia de las subespecies longicaudatus y philippi y dejando esta última en sinonimia como $O$. longicaudatus tal como lo habían propuesto estudios anteriores. El rango de $O$. longicaudatus se amplía hasta Torres del Paine ca. $51^{\circ}$ de latitud sur. El descarte de subespecies es debido a los bajos valores de secuencia de divergencia nucleotídica y a la ausencia de asociaciones significativas entre los haplotipos y su geografía. Adicionalmente, reconocemos que la entrada de esta especie hacia el lado chileno ocurrió a través de los bosques Patagónicos del sur de Argentina, luego de lo cual la especie se dispersó hacia el norte de Chile, desde el sur.

\section{ACKNOWLEDGMENTS}

We thank M. F. Smith and C. Yahnke for their helpful comments on an early version of the manuscript, and G. D'Elia and S. Steppan for their assistance at different stages of this work. We also appreciate the 
loan of specimens from the Instituto de la Patagonia (C. Venegas). Special thanks go to the Hanta and the Peridomestic crews of the Chilean Hantavirus Project for field collection of specimens: S. Alvarado, A. Charrier, M. Eherenfeld, J. González, G. Lobos, R. Medina, J. Navarrete-Droguett, and H. Vallejos; and to S. Cirignoli, F. Cremonte, and D. Podestá in Argentina. We are also grateful for the laboratory assistance of D. Boric-Bargetto, F. Martelli, and E. Rodriguez. I. Barría provided us with the map used in Fig. 1. We thank Corporación Nacional Forestal (CONAF) and Servicio Agrícola y Ganadero (SAG) for allowing us to capture mice in protected and unprotected areas of Chile, and the Dirección Provincial de Fauna del Neuquén (via A. del Valle) in Argentina. We greatly appreciate financial support from grants "Hantavirus ecology and disease in Chile" (National Institute of Health-ICIDR 1 U19 AI45452-01 to The University of New Mexico, USA, and to the Pontificia Universidad Católica de Chile, Chile), CONACYT (Argentina), and FONDECYT 1030488 (Chile).

\section{Literature Cited}

AKAIKE, H. 1974. A new look at the statistical model identification. IEEE Transactions on Automatic Control 19:716-723.

Animal Care and Use Committee. 1998. Guidelines for the capture, handling, and care of mammals as approved by The American Society of Mammalogists. Journal of Mammalogy 79:1416-1431.

Armesto, J. J., M. T. K. Arroyo, and L. F. Hinojosa. In press. The Mediterranean environment. In The physical geography of South America (T. Veblen, K. Young and A. Orne, eds.). Oxford University Press, New York.

Bibb, M. J., R. A. VanEtten, C. T. Wright, and M. W. Walberg. 1981. Sequence and gene organization of mouse mitochondrial DNA. Cell 26:167-180.

Bohlman, M. C., ET AL. 2002. Analysis of hantavirus genetic diversity in Argentina: S segment-derived phylogeny. Journal of Virology 76:3765-3773.

Carleton, M. D., and G. G. Musser. 1989. Systematic studies of oryzomyine rodents (Muridae, Sigmodontinae): a synopsis of Microryzomys. Bulletin of the American Museum of Natural History 191:1-83.

Clement, M., D. Posada, and K. Crandall. 2000. TCS: a computer program to estimate gene genealogies. Molecular Ecology 9:16571660.

Dickerman, A. W., And T. L. Yates. 1995. Systematics of Oligoryzomys: protein electrophoretic analyses. Journal of Mammalogy 76:172-188.

Edwards, S. V., P. Arctander, And A. C. Wilson. 1991. Mitochondrial resolution of a deep branch in the genealogical tree for perching birds. Proceedings of the Royal Society of London, B. Biological Sciences 243:99-107.

Excoffier, L., P. Smouse, And J. Quattro. 1992. Analysis of molecular variance inferred from metric distances among DNA haplotypes: application to human mitochondrial DNA restriction data. Genetics 131:479-491.

Felsenstein, J. 1985. Confidence limits on phylogenies: an approach using the bootstrap. Evolution 39:783-791.

Gallardo, M. H., and R. E. Palma. 1990. Systematics of Oryzomys longicaudatus (Rodentia: Muridae) in Chile. Journal of Mammalogy 71:333-343.

Gallardo, M. H., and B. D. Patterson. 1985. Chromosomal differences between two nominal subspecies of Oryzomys longicaudatus Bennett. Mammalian Chromosomes Newsletter 25:49-53.

González-Ittig, R. E., G. R. Theiler, and C. N. Gardenal. 2002. A contribution to the subgeneric systematics of Oligoryzomys
(Rodentia, Muridae) from Argentina by means of PCR-RFLP patterns of mitochondrial DNA. Biochemical Systematics and Ecology 30:23-33.

Higgins, D. G., J. D. Thompson, And T. J. Gibson. 1996. Using CLUSTAL for multiple sequence alignment. Methods in Enzymology 266:383-402.

Holling, J. T., AND D. H. Schilling. 1981. Late WisconsinWeichselian mountain glaciers and small ice caps. Pp. 179-206 in The last great ice sheets (G. H. Denton and T. J. Hughes, eds.). John Wiley \& Sons, Inc., New York.

Ibrahim, K. M., R. A. Nichols, And G. M. Hewitt. 1996. Spatial patterns of genetic variation generated by different forms of dispersal during range expansion. Heredity 77:282-291.

Kelt, D. A., P. L. Meserve, and B. K. Lang. 1994. Quantitative habitat associations of small mammals in a temperate rainforest in southern Chile: empirical patterns and the importance of ecological scale. Journal of Mammalogy 75:890-904.

Kumar, S., K. Tamura, and M. Nei. 1993. MEGA: Molecular evolutionary genetics analysis, version 1.01. Pennsylvania State University, University Park.

Laird, P. W., A. Zijderveld, K. Linders, M. A. Rudnicki, R. JAENISCH, AND A. BERNS. 1991. Simplified mammalian DNA procedure. Nucleic Acid Research 19:4293.

LIEDLOFF, A. 1999. MANTEL, Mantel nonparametric test calculator, version 2. 0. Queensland University of Technology, Queensland, Australia.

MAnN, G. 1978. Los pequeños mamíferos de Chile. Gayana, Zoología 40:1-342.

MANTEL, N. 1967. The detection of disease clustering and a generalized regression approach. Cancer Research 27:209-220.

Mares, M. A., R. A. OjedA, ANd R. M. Barquez. 1989. Guide to the mammals of Salta Province, Argentina. Oklahoma Museum of Natural History Publications, Norman.

Massoia, E. 1973. Presencia y rasgos bioecológicos de Oryzomys longicaudatus pampanus, nueva subespecie en la provincia de Buenos Aires (Mammalia, Rodentia, Cricetidae). Revista de Investigaciones Agropecuarias INTA Serie I Biología y Producción Animal 10:43-49.

Mercer, J. H. 1983. Cenozoic glaciation in the Southern Hemisphere. Annual Review of Earth and Planetary Sciences 11:99-132.

Meserve, P. L., D. A. Kelt, W. B. Milstead, J. R. Gutiérrez, and J. H. Brown. 2003. Thirteen years of shifting top-down and bottomup control. BioScience 53:633-646.

Monjeau, J., E. Birney, L. Ghermandi, R. Sikes, L. Margutti, and C. Phillips. 1998. Plants, small mammals, and the hierarchical landscape classifications of Patagonia. Landscape Ecology 13:285306.

Moreno, P. I., T. V. Lowell, J. R. Jacobson, JR., And G. H. Denton. 1999. Abrupt vegetation and climate changes during the last glacial maximum and last termination in the Chilean Lake District: a case study from Canal de la Puntilla $\left(41^{\circ} \mathrm{S}\right)$. Geografiska Annaler 81:285-311.

MurRAY, V. 1989. Improved double-stranded DNA sequencing using the linear polymerase chain reaction. Nucleic Acid Research 17:8889.

MurúA, R., L. A. González, And P. L. Meserve. 1986. Population ecology of Oryzomys longicaudatus philippi (Rodentia: Cricetidae) in southern Chile. Journal of Animal Ecology 55:281-293.

Musser, G. G., And M. D. Carleton. 1993. Order Rodentia. Pp. 501756 in Mammal species of the world: a taxonomic and geographic reference (D. E. Wilson and D. M. Reeder, eds.). Smithsonian Institution Press, Washington, D.C. 
Myers, P., B. Lundrigan, and P. K. Tucker. 1995. Molecular phylogenetics of oryzomyine rodents: the genus Oligoryzomys. Molecular Phylogenetics and Evolution 4:372-382.

Osgood, W. H. 1943. The mammals of Chile. Field Museum of Natural History, Zoology Series 30:1-268.

Padula, P. J., ET AL. 2000. Genetic diversity, distribution, and serological features of Hantavirus infection in five countries in South America. Journal of Clinical Microbiology 38:3029-3035.

Palma, R. E. 1987. Sistemática evolutiva del género Oryzomys Baird en Chile (Rodentia: Cricetidae). M.Sc. thesis, Universidad Austral de Chile, Valdivia.

Pardiñas, U. F. J., G. D'Elía, ANd P. E. Ortiz. 2002. Sigmodontinos fósiles (Rodentia, Muroidea, Sigmodontinae) de América del Sur: Estado actual de su conocimiento y prospectiva. Journal of Neotropical Mammalogy 9:209-252.

Pearson, O. P. 1983. Characteristics of mammalian faunas from forests in Patagonia, southern Argentina. Journal of Mammalogy. 64:476-492.

Pearson, O. P. 1987. Mice and the postglacial history of the Traful Valley of Argentina. Journal of Mammalogy 68:469-478.

Posada, D., And K. A. Crandall. 1998. Modeltest: testing the model of DNA substitution. Bioinformatics 14:817-818.

Posada, D., K. A. Crandall, and A. R. Templeton. 2000. GeoDis: a program for the cladistic nested analysis of the geographical distribution of genetic haplotypes. Molecular Ecology 9:487-488.

REDFORD, K. H., AND J. F. EISENBERG. 1992. Mammals of the Neotropics: the southern cone, Chile, Argentina, Uruguay, Paraguay. University of Chicago Press, Chicago, Illinois.

REIG, O. A. 1986. Diversity patterns and differentiation of high Andean rodents. Pp 404-439 in High altitude tropical biogeography (F. Vuilleumier and M. Monasterio, eds.). Oxford University Press, New York.

Rogers, A. R., AND H. HaRpending. 1992. Population growth makes waves in the distribution of pairwise genetic distance. Molecular Biology and Evolution 9:552-569.

Schneider, S., D. Roessli, And L. Excoffier. 2000. Arlequin ver. 2000: a software for population genetics data analysis. Genetics and Biometry Laboratory, University of Geneva, Geneva, Switzerland.

Smith, M. F., D. A. Kelt, and J. L. Patton. 2001. Testing models of diversification in mice in the Abrothrix olivaceus/xanthorhinus complex in Chile and Argentina. Molecular Ecology 10:397-405.
Smith, M. F., AND J. L. Patton. 1993. The diversification of South American murid rodents: evidence from mitochondrial DNA sequence data for the akodontine tribe. Biological Journal of the Linnean Society 50:149-177.

Smith, M. F., And J. L. Patton. 1999. Phylogenetic relationships and radiation of sigmodontine rodents in South America: evidence from cytochrome $b$. Journal of Mammalian Evolution 6:89-128.

StePPAN, S. J. 1998. Phylogenetic relationships and species limits within Phyllotis (Rodentia: Sigmodontinae): concordance between mtDNA sequence and morphology. Journal of Mammalogy 79:573-593.

Swofford. D. L. 2002. PAUP*: phylogenetic analyses using parsimony (* and other methods). Version 4.0. Sinauer Associates, Inc., Publishers, Sunderland, Massachusetts.

Templeton A. R. 2004. Statistical phylogeography: methods of evaluating and minimizing inference errors. Molecular Ecology 13:789-809.

Templeton, A. R., K. A Crandall, and C. F. Sing. 1992. A cladistic analysis of phenotypic associations with haplotypes inferred from restriction endonuclease mapping and DNA sequence data. III. Cladogram estimation. Genetics 132:619-633.

Templeton, A. R., E. Routman, and C. A. Phillips. 1995. Separating population structure from population history: a cladistic analysis of the geographical distribution of mitochondrial DNA haplotypes in the tiger salamander, Ambyostoma tigrinum. Genetics 140:767-782.

TORO, J., ET AL. 1998. An outbreak of hantavirus pulmonary syndrome, Chile, 1997. Emerging Infectious Disease 4:687-694.

ViLLAGRÁn, C. 1990. Glacial climates and their effects on the history of vegetation of Chile: a synthesis based on palynological evidence from Isla de Chiloé. Revue of Palaeobotany and Palynology 65: $17-24$.

Villagrán, C., AND L. F. Hinojosa. 1997. Historia de los bosques de Sudamérica, II: Análisis fitogeográfico. Revista Chilena de Historia Natural 70:241-267.

Submitted 26 December 2003. Accepted 16 April 2004.

Associate Editor was Eric A. Rickart. 


\section{APPENDIX I}

List of Oligoryzomys taxa sequenced for the cytochrome $b$ gene. Tissue number is collection number, Accession number is GenBank accession number, source is Museum or Collection where vouchers were deposited. Locality numbers are shown on map (Fig. 1); haplotype numbers were obtained using the TCS program (Fig. 3; Clement et al. 2000).

\begin{tabular}{|c|c|c|c|c|c|c|c|c|c|c|}
\hline Taxon & $\begin{array}{c}\text { Tissue } \\
\text { number }\end{array}$ & $\begin{array}{l}\text { Locality } \\
\text { on the } \\
\text { map }\end{array}$ & $\begin{array}{c}\text { Haplotype } \\
\text { number }\end{array}$ & Locality & Region & Country & Latitude & Longitude & $\begin{array}{c}\text { GenBank } \\
\text { Accession } \\
\text { number }\end{array}$ & Source $^{a}$ \\
\hline \multirow[t]{33}{*}{ longicaudatus } & 96860 & 1 & 1 & La Silla & Coquimbo & Chile & $29^{\circ} 13^{\prime} 58^{\prime \prime} \mathrm{S}$ & $70^{\circ} 44^{\prime} 14^{\prime \prime} \mathrm{W}$ & AY 275682 & SSUC/MSB \\
\hline & 16.4 & 2 & 2 & Fray Jorge & Coquimbo & Chile & $30^{\circ} 38^{\prime} 58^{\prime \prime} \mathrm{S}$ & $71^{\circ} 41^{\prime} 14^{\prime \prime} \mathrm{W}$ & AF 346572 & SSUC \\
\hline & 95268 & 3 & 3 & Salamanca & Coquimbo & Chile & $31^{\circ} 53^{\prime} 12^{\prime \prime} \mathrm{S}$ & $70^{\circ} 47^{\prime} 47^{\prime \prime} \mathrm{W}$ & AF 346570 & SSUC/MSB \\
\hline & 96758 & 4 & 4 & Quebrada del Tigre & Valparaíso & Chile & $32^{\circ} 33^{\prime} 36^{\prime \prime} \mathrm{S}$ & $71^{\circ} 26^{\prime} 19^{\prime \prime} \mathrm{W}$ & AY 275683 & SSUC/MSB \\
\hline & 95299 & 5 & 5 & Apoquindo & Metropolitana & Chile & $33^{\circ} 24^{\prime} 13^{\prime \prime} \mathrm{S}$ & $70^{\circ} 29^{\prime} 01^{\prime \prime} \mathrm{W}$ & AF 346568 & SSUC/MSB \\
\hline & 96789 & 6 & 6 & Rinconada de Maipú & Metropolitana & Chile & $33^{\circ} 29^{\prime} 44^{\prime \prime} \mathrm{S}$ & $70^{\circ} 53^{\prime} 39^{\prime \prime} \mathrm{W}$ & AY 275685 & SSUC/MSB \\
\hline & 105860 & 7 & 7 & San Antonio & Valparaíso & Chile & $33^{\circ} 34^{\prime} 07^{\prime \prime} \mathrm{S}$ & $71^{\circ} 37^{\prime} 16^{\prime \prime} \mathrm{W}$ & AY 275684 & SSUC/MSB \\
\hline & 105929 & 8 & 8 & San Fernando & $\mathrm{O}^{\prime}$ Higgins & Chile & $34^{\circ} 45^{\prime} 59^{\prime \prime} \mathrm{S}$ & $70^{\circ} 46^{\prime} 34^{\prime \prime} \mathrm{W}$ & AY 275686 & SSUC/MSB \\
\hline & 105931 & 9 & 9 & Romeral & Maule & Chile & $34^{\circ} 58^{\prime} 05^{\prime \prime} \mathrm{S}$ & $71^{\circ} 07^{\prime} 34^{\prime \prime} \mathrm{W}$ & AY 275687 & SSUC/MSB \\
\hline & 105885 & 10 & 10 & Bullileo & Maule & Chile & $36^{\circ} 17^{\prime} 20^{\prime \prime} \mathrm{S}$ & $71^{\circ} 24^{\prime} 47^{\prime \prime} \mathrm{W}$ & AY 275688 & SSUC/MSB \\
\hline & 105827 & 11 & 11 & Quillón & Bío-Bío & Chile & $36^{\circ} 42^{\prime} 46^{\prime \prime} \mathrm{S}$ & $72^{\circ} 34^{\prime} 18^{\prime \prime} \mathrm{W}$ & AY 275689 & SSUC/MSB \\
\hline & 105977 & 12 & 12 & Tucapel & Bío-Bío & Chile & $37^{\circ} 14^{\prime} 28^{\prime \prime} \mathrm{S}$ & $71^{\circ} 47^{\prime} 38^{\prime \prime} \mathrm{W}$ & AY 275690 & SSUC/MSB \\
\hline & 95614 & 14 & 14 & Carahue & Araucanía & Chile & $38^{\circ} 30^{\prime} 55^{\prime \prime} \mathrm{S}$ & $73^{\circ} 06^{\prime} 59^{\prime \prime} \mathrm{W}$ & AF 346571 & SSUC/MSB \\
\hline & 95573 & 15 & 15 & Temuco & Araucanía & Chile & $38^{\circ} 41^{\prime} 20^{\prime \prime} \mathrm{S}$ & $72^{\circ} 36^{\prime} 48^{\prime \prime} \mathrm{W}$ & AY 275691 & SSUC/MSB \\
\hline & 95370 & 17 & 17 & Quetrupillán & Araucanía & Chile & $39^{\circ} 25^{\prime} 38^{\prime \prime} \mathrm{S}$ & $71^{\circ} 47^{\prime} 16^{\prime \prime} \mathrm{W}$ & AY 275693 & SSUC/MSB \\
\hline & 95083 & 18 & 18 & Villarrica & Araucanía & Chile & $39^{\circ} 27^{\prime} 28^{\prime \prime} \mathrm{S}$ & $71^{\circ} 49^{\prime} 33^{\prime \prime} \mathrm{W}$ & AF 346566 & SSUC/MSB \\
\hline & 95048 & 19 & 19 & Villarrica & Araucanía & Chile & $39^{\circ} 27^{\prime} 19^{\prime \prime} \mathrm{S}$ & $71^{\circ} 49^{\prime} 11^{\prime \prime} \mathrm{W}$ & AY 275692 & SSUC/MSB \\
\hline & 96972 & 21 & 21 & Panguipulli & Los Lagos & Chile & $39^{\circ} 44^{\prime} 12^{\prime \prime} \mathrm{S}$ & $72^{\circ} 13^{\prime} 39^{\prime \prime} \mathrm{W}$ & AY 275694 & SSUC/MSB \\
\hline & 104559 & 22 & 22 & Riñihue & Los Lagos & Chile & $39^{\circ} 48^{\prime} 15^{\prime \prime} \mathrm{S}$ & $72^{\circ} 19^{\prime} 15^{\prime \prime} \mathrm{W}$ & AY 275695 & SSUC/MSB \\
\hline & 95659 & 23 & 23 & Chiloé & Los Lagos & Chile & $41^{\circ} 52^{\prime} 57^{\prime \prime} \mathrm{S}$ & $73^{\circ} 40^{\prime} 08^{\prime \prime} \mathrm{W}$ & AF 346573 & SSUC/MSB \\
\hline & 95656 & 24 & 24 & Chiloé & Los Lagos & Chile & $41^{\circ} 52^{\prime} 59^{\prime \prime} \mathrm{S}$ & $73^{\circ} 40^{\prime} 20^{\prime \prime} \mathrm{W}$ & AY 275696 & SSUC/MSB \\
\hline & 96562 & 25 & 25 & Río Simpson & Aysén & Chile & $45^{\circ} 27^{\prime} 42^{\prime \prime} \mathrm{S}$ & $72^{\circ} 19^{\prime} 21^{\prime \prime} \mathrm{W}$ & AY 275698 & SSUC/MSB \\
\hline & 95245 & 26 & 26 & Mininco & Aysén & Chile & $45^{\circ} 31^{\prime} 03^{\prime \prime} \mathrm{S}$ & $71^{\circ} 51^{\prime} 49^{\prime \prime} \mathrm{W}$ & AF 346567 & SSUC/MSB \\
\hline & 95268 & 27 & 27 & Mininco & Aysén & Chile & $45^{\circ} 30^{\prime} 44^{\prime \prime} \mathrm{S}$ & $71^{\circ} 47^{\prime} 25^{\prime \prime} \mathrm{W}$ & AY 275697 & SSUC/MSB \\
\hline & 95957 & 28 & 28 & Río Ibañez & Aysén & Chile & $46^{\circ} 05^{\prime} 09^{\prime \prime} \mathrm{S}$ & $72^{\circ} 34^{\prime} 52^{\prime \prime} \mathrm{W}$ & AY 275699 & SSUC/MSB \\
\hline & 105649 & 30 & 31 & Torres del Paine & Magallanes & Chile & $51^{\circ} 07^{\prime} 24^{\prime \prime} \mathrm{S}$ & $73^{\circ} 07^{\prime} 47^{\prime \prime} \mathrm{W}$ & AY 452197 & SSUC/MSB \\
\hline & 105650 & 30 & 32 & Torres del Paine & Magallanes & Chile & $51^{\circ} 07^{\prime} 24^{\prime \prime} \mathrm{S}$ & $73^{\circ} 07^{\prime} 47^{\prime \prime} \mathrm{W}$ & AY 452198 & SSUC/MSB \\
\hline & 1025 & 31 & 33 & Río Penitente & Magallanes & Chile & $52^{\circ} 06^{\prime} 45^{\prime \prime} \mathrm{S}$ & $71^{\circ} 32^{\prime} 10^{\prime \prime} \mathrm{W}$ & AY 275706 & CZIP \\
\hline & UP 449 & 13 & 13 & Chos Malal & Neuquén & Argentina & $37^{\circ} 23^{\prime} 15^{\prime \prime} \mathrm{S}$ & $70^{\circ} 16^{\prime} 40^{\prime \prime} \mathrm{W}$ & AY 275701 & CENPAT \\
\hline & UP 435 & 16 & 16 & Zapala & Neuquén & Argentina & $38^{\circ} 50^{\prime} \mathrm{S}$ & $70^{\circ} 30^{\prime} \mathrm{W}$ & AY 275700 & CENPAT \\
\hline & LB 012 & 20 & 20 & Las Breñas & Neuquén & Argentina & $39^{\circ} 23^{\prime} \mathrm{S}$ & $71^{\circ} 12^{\prime} \mathrm{W}$ & AY 275702 & CENPAT \\
\hline & UP 374 & 29 & 29 & Bahía San Blas & Buenos Aires & Argentina & $40^{\circ} 33^{\prime} \mathrm{S}$ & $62^{\circ} 13^{\prime} \mathrm{W}$ & AY 275703 & CENPAT \\
\hline & UP 377 & 29 & 30 & Bahía San Blas & Buenos Aires & Argentina & $40^{\circ} 33^{\prime} \mathrm{S}$ & $62^{\circ} 13^{\prime} \mathrm{W}$ & AY 275704 & CENPAT \\
\hline fornesi & GD010 & & & 620 m S Hotel Centu Cue & Misiones & Paraguay & $26^{\circ} 15^{\prime} 06^{\prime \prime} \mathrm{S}$ & $57^{\circ} 1^{\prime} 35^{\prime \prime} \mathrm{W}$ & AY 452199 & GD \\
\hline
\end{tabular}

${ }^{a}$ SSUC: Colección de Flora y Fauna Profesor Patricio Sánchez Reyes, Pontificia Universidad Católica de Chile, Chile; MSB: Museum of Southwestern Biology, University of New

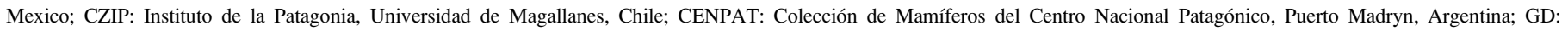
Guillermo Delía catalog (Uruguay). 